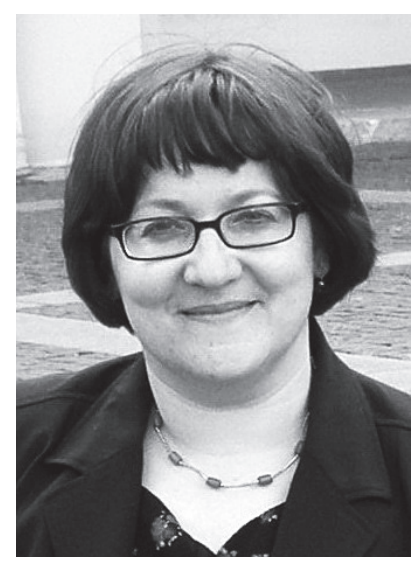

Rūta Kazlauskaitė - humanitarinių mokslų daktaré, Šiaulių universiteto Humanitarinio fakulteto Lietuvių kalbotyros ir komunikacijos katedros docentè.

Moksliniai interesai: sakytinė kalba, dialektologija, teksto lingvistika ir pragmatika.

Adresas: Povilo Višinskio g. 38, LT-76352 Šiauliai.

Tel. $(8 \sim 41) 595785$.

El. paštas: kazlauskaite@takas.lt.

Rūta Kazlauskaitè: Ph. D. in Humanities, Associate Professor of the Department of Lithuanian Language and Communication, Šiauliai University.

Research interests: spoken language, dialectology, text linguistics, pragmatics.

Address: Povilo Višinskio str. 38, LT-76352 Šiauliai.

Phone: $(8 \sim 41) 595785$.

E-mail: kazlauskaite@takas.lt.

\title{
Rūta Kazlauskaitè
}

Šiaulių universitetas

\section{ŽYDINČ IOS SAULËGRĄŽOS VAIZDINYS LIETUVIŲ POEZIJOJE}

\begin{abstract}
Anotacija
Pristatomo tyrimo tikslas - išanalizuoti lietuvių autorių eilèraščių fragmentų kalbinę raišką ir aptarti išryškejjusią žydinčios saulègrąžos įvaizdžių semantinę paradigmą. Metodologinis tyrimo pagrindas yra kognityvinė lingvistika. Straipsnis parodo, kad poezijoje aktualizuojamos rẽgimosios žydinčios saulègrąžos ypatybės. Saulėgrąža suvokiama kaip tam tikros formos didelis švytintis, galintis judèti (svyruoti, siūbuoti ir kelti, lenkti, sukti žiedyną i c saulę) arba išlaikyti pusiausvyrą objektas. Šie požymiai yra augalo pavadinimų metaforizacijos pagrindas.
\end{abstract}

PAGRINDINIAI ŽODŽIAI: saulègrąža, poezija, vaizdinys, kategorizavimas, reikšmè, metafora.

\section{Abstract}

The aim of the present research is to analyse and to discuss the linguistic expressions and the semantic paradigm of the images of the sunflower in bloom that have formed in Lithuanian poetry. The methodological basis of the research is cognitive linguistics. The paper verifies that visual features of the sunflower in bloom are emphasized in poetry. The sunflower is perceived as a large in shape object that shines and moves (swings, sways and rises, bends, turns to the sun) or keeps one's balance. The indicated features are the basis of metaphorical names of the plant.

KEY WORDS: sunflower, poetry, mental image, categorization, meaning, metaphor.

DOI: http://dx.doi.org/10.15181/ rh.v0i16.1014 
Kalbinès raiškos pasirinkimas, kalbos vartosena neatsiejami nuo pažintinių, arba kognityvinių, procesų. Išnagrinejjus tikrovès segmento įvardijimo kuria nors kalba būdus ir priemones, išryškejja tą kalbą vartojančios visuomenès gyvenimo patirtis, mąstymo ir jausenos savitumas, vertybinė orientacija - naiviojo kolektyvinio pasaulėvaizdžio elementai. Tyrimas, atliktas pritaikius kognityvinès lingvistikos principus, pateikia įvairiu duomenų apie žmogaus prigimtį, pirmiausia jo aplinkos kategorizavimą ir konceptualizavimą (Smith 1993, 351)1.

Straipsniu pristatomo tyrimo tikslas - apibrezžti lietuvių autorių poezijoje susidèliojusį žydinčios saulègrąžos vaizdinį. Analizuojamoji medžiaga - 70 poetų sukurti 120 eilèraščių ar jų fragmentų. Išsikelti tokie darbo uždaviniai: nustatyti svarbiausius vaizduojamojo objekto - kalbamojo augalo, jo žiedyno, atskirų žiedų pagrindinius požymius ir būdinguosius veiksmus (atributus); aptarti tiesioginius ir perkeltinius saulègrąžos pavadinimus, pag rịsti vartojamas metaforas; konceptualiuoju lygmeniu įvertinti saulègrąžu žydejjimo reiškinị. Pagrindinis darbo metodas - kognityvinès semantinès analizės. Jis tinka norint atskleisti pažinimo struktūru kalbines reprezentacijas ir informacijos apdorojimo principus (plg. Демьянков 1994, 21). Tyrimu tęsiami artimos tematikos darbai: jau išanalizuoti ir aprašyti aguonos ir vyšnios - prototipinių raudonai ir baltai žydinčių augalų - vaizdiniai (žr. Kazlauskaitė 2010; 2011).

Vaizduojamojo objekto ypatybès. Daiktavardžio saulègrąža definicija Dabartinés lietuviu kalbos žodyne iškelia du augalo ypatumus: paskirti ir taksono rangą - bot. „kultūrinis aliejinis ir silosinis graižažiedžių šeimos augalas (Helianthus); jo sẻkla“ (DLKŽ $\left.{ }_{7} 677\right)$. Enciklopedinio pobūdžio mokslo darbuose (žr., pavyzdžiui, LF VI, 70-71; Vilkonis 2001, 288; ŽŪE III, 221) pateikiama ịvairesnių duomenų. Nurodoma, kad tikroji saulègrąža (Helianthus annuus) yra laukuose, daržuose ir gèlynuose auginamas vienmetis žolinis augalas, turintis apie $2,5 \mathrm{~m}$ (kartais netgi $5-8 \mathrm{~m}$ ) aukščio šakotą medèjantị stiebą. Stiebo viršuje susiformuojantys žiedai yra susitelkę i grupes - sudaro $15-30 \mathrm{~cm}$ (kartais iki $70 \mathrm{~cm}$ ) skersmens žiedynus; kraštiniai žiedai yra liežuviški, jie bevaisiai, o vidiniai - vamzdiški ir vaisingi. Saulègrąžų žydejjimo laikas - liepos-spalio mėnesiai. Tai maistinis, vaistinis, dažinis augalas.

1 Suprantama, naivusis pasaulio vaizdas, kitaip negu mokslinis, priklauso ir nuo kalbos, kuria jis aprašomas (žr. Апресян 1974, 59). 
Stiebo aukštumas ir graižo didumas saulègrąžas išskiria iš kitų žoliniu augalų. Dar vienas augalo savitumas tas, kad graižą sudarantys žiedai yra dvejopo pavidalo ir atspalvio: ryškiai geltoni vainiku išsidèstę kraštiniai žiedai, arba skraistlapiai, yra platūs ir ilgi $(6-10 \mathrm{~cm}$ ilgio), smailejjantys, o rudai geltoni, rusvi ar rausvai rudi vidiniai žiedai yra kur kas mažesnès apimties - jie susisukę, primena vamzdelius. Žiedai, ypač kraštiniai, šnekamojoje kalboje dažnai vadinami vainiklapiais.

Poetai dèmesị sutelkia ị ryškiausias žydinčiu saulèg rąžų ypatybes:

- galejjimą judèti: keisti viso stiebo arba viršutinès stiebo dalies (lapu, graižo, žiedų) padètį;

- augalų stiebo aukštį, žiedyno ir atskirų žiedų dydį, formą ir žydinčių augalų plotų beribiškumą;

- spalvą.

Visos trys ypatybės suvokiamos rega. Jos eina metaforizacijos pagrindu, todèl yra skiriamosios (relevantinès). Metaforos ${ }^{2}$ analizuojant vaizdinius labai svarbios. Jos visų pirma rodo pažinimo procesus (Stambovsky 1988, 21; plg. Wagner, Radner 1974, 91), todèl gerokai papildo, o poezijoje ir nusveria tiesioginès raiškos priemonėmis perduodamą turinį. Valentina Maslova teigia, kad norint suvokti metaforų esmę reikia nustatyti ir suderinti aptariamojo objekto savybes; atliekant šị darbą neišleistinas iš akių faktas, kad „daiktiškumo požymis metaforizavimo metu gali būti perduotas ne tik daiktu, o veiksmo požymis - veiksmu, bet ir aplinkiniais būdais: daikto požymis veiksmu ir t. t.“ (Маслова 1997, 70).

Išskirtas ypatybes liudija sukauptuose eileraščiuose aptikti denotato pavadinimai: termininis ir aprašomieji. Fitonimas saulègrąža rodo, kad auga-

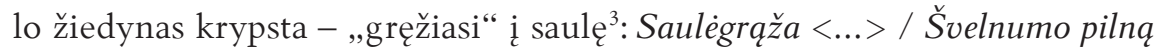
$\check{z} v i \lg s n i$ suka saulèn J. Lin. ${ }^{4}$ Poezijoje šis vardas ịprasčiausias, jis vie-

2 Metaforomis darbe laikomi ir palyginimai - neredukuota asociatyviojo mąstymo raiškos forma.

3 Krypimo ị saulę ypatybè ịkoduota ir latvių kalbos pavadinime saulgieze (latviai turi ir kitą pavadinimą - saulespuķe), italų - girasole (gira(re) 'pasisukti' ir sole 'saulè'), bulgarų - сльнчоглед (сльнце 'saulë' ir гледам 'žiūrèti'). Daugelio kitų indoeuropiečių kalbų pavadinimai iškelia graižo panašumą i saulę: lotynų - Helianthus (hēlios 'saulè' ir anthos 'žiedas'), anglu - sunflower, vokiečiu - sonnenblume, švedų - solros, rusų - подсолнечник (ir šnek. подсолнух), lenkų - słonecznik.

4 Metafizinį saulès ir saulègrąžos ryši rodo ir tokie pavyzdžiai, kaip van gogiška saule trenkia / vaikščiodama po darža, i eš ko da ma / saulegrąžų. J. Švab. 
nintelis vienažodis ${ }^{5}$. Dviejuose Juditos Vaičiūnaitès kūriniuose pavartoti jo sudètiniai atitikmenys - perifrazès šviesomégis augalas, saulès gèlè ir žalio indèniško kraujo gèlè: Su spindulių spygliais / saulutè ir saulainè, / ir saulenis, ir saulègrąža, / ir saulašarè / šviesomègiai augalai; skurdybëj tos vasaros / saulès gèlè, šitaip permainingai / gręžus nuauksinta veida pro dulkiu debesis; Vilniuj, Totoriu gatvès statybvietëj, / užpernai augus saulègrąža - / žalio indèniško kraujo gèlè, / visados atsigręžus j saulę, / buvo tos vasaros simbolis. Perifrazių daiktavardžiai augalas ir gèle saulègrąžą priskiria organizmams, kurie augdami naudoja šviesos energiją. Tai patvirtina augalo epitetas šviesomégis. Jis metaforinis, paremtas asociacijomis, kaip ir daiktavardiniai gèlès epitetai saulès ir žalio indèniško kraujo. Asociatyvusis mąstymas leidžia susieti, t. y. priskirti vienai tikrovės kategorijai, visus tų pačiu atributų turètojus - šiuo atveju objektus, pasižyminčius požymiais 'ryškus', 'apvalus' arba 'beformis, tąsus': saulègrąžos graižą ir šviečiantị dangaus kūną (saulę), to kūno skleidžiamus spindulius; saulègrąžos graižą ir žmogaus (indèno) kūno dalies - galvos apdarą, kūno audinius maitinantị skystį (šių požymių turètojai aptariami skyriuje „Dydžio ir formos ypatybès raiška“).

Porą kartų surinktuose pavyzdžiuose paminètos uosle ir klausa suvokiamos saulègrąžų ypatybès - kvapas ir vejjo judinamų lapų garsas: Užlieja mane tenai / saulegrąžų, žemès ir žydinčiu vyšnių kvapas. H. Nag.; dar aš jos [saulègrąžos] ${ }^{6}$ šnaresio vejjy klausau J. Vaič. Šios ypatybès šalutinès, nes apibūdina ne tiek augalą, kiek šalia jo esantị žmogų. Laikantis kognityvizmo terminijos, gamtinè realija šiuo atveju yra fonas; teikdama malonių potyrių, gamta įprasmina žmogaus - figūros tame fone - buvimą.

Panašiai vertintina identifikuojamoji saulègrąžos ypatybè - žydejjimas. ‘Žydejjimo’ reikšmès žodžiai nukreipia į žmogų, apibrèžia jo vidinio pasaulio būklę (plg. Kazlauskaitè 2010, 55).

Saulègrąžų žydejjimo pradžią, drauge ir sielos nuskaidrèjimo momentą žymi veiksmažodžių formos pražysta, pražydo, išsprogus, taip pat žieda sukrauna (4 pavyzdžiai); besitęsiantị žydejjimą, arba energijos išlydị, veiksmažodžio žydèti formos žydi, žydèk, žydètų, žydinčiu (8 pavyzdžiai); artẻjimą prie žydejjimo pabaigos ir pačią pabaigą, kitaip tariant, minorinę

\footnotetext{
Tarminius pavadinimus, tarp kurių yra ir keliažodžių, žr. Gritėnienė 2006, 150-151.

İrašu laužtiniuose skliaustuose aiškinama mintis, o daugtaškiu kampiniuose skliaustuose žymima praleista cituojamų pavyzdžių dalis.
} 
gaidą, - žydeti stengiasi, meta žiedlapi (2 pavyzdžiai), pvz.: Visas visas horizontas / Saulemis pražydo. R. Petr.; Tame pasaulyje [ị kurị ateis kūdikis] $\check{z} y d i$ / Saulegražǒs ir joniniu paparčiai. B. Rib.; Ir tyloje [saulègrąža] savus vaikus maitina. / Trumpiau žydèti stengiasi kas dienq, / <...> Ji meta žiedlapị. J. Lin. I dvasinị pakylèjimą, tikèjimą, trokštamą laimę kreipia su aptartaisiais veiksmažodžiais derinami daiktavardžiai horizontas, saulé, širdis, kūdikis, vaikas, joniniu paparčiai ir pan.

Kalbamasis augalas poezijos pasaulyje yra ịkurdintas arti žmogaus, jo namų. 11 pavyzdžių nurodoma, kad jis auginamas darže, kur nusvyra ị tarplysui, daržely, po langais, lange 'už lango', prie lango, auga pakelejje, prie Arlio - miestelio pietų Prancūzijoje ir, puošiant kambarị, laikomas vazone ar pamerktas ant stalo, pvz.: Kuo skiriasi saulegraža / Nuo skaisčios saulès? / Viena - darže, / O kita - dangaus akyse. O. Bal.; O daržuos - jurginai, kvepia kmynai, / tarplysvy saulegrazžos pasviro... T. Rost.; Bet šiq akimirkq / viename lange spindi menno, / kitam lange teka saule, / trečiame lange - saulègrazžu veidrodžiai. J. Jov.; Prie Arlio, Dieve, tu regëjai gaisra / Kviečiu kalvu saulegrąžu auksiniu L. Gut.; Atidarau duris. <...> Skurdūs baldai, saulegrąžos senam vazone. J. Zdan. Rečiau, 7 kartus, poezijoje minimi saulėgrąžos ar saulègrąžu atvaizdai: piešinys knygoje ar ant delno, drobejje tapyti paveikslai, fotografija, pvz.: Dar pasèdesim aplink balta staltiesę / ir pakvépuosim saulegrąžu šviesa iš atverstos knygos. J. Jek.; Saulegrąža esu / ant delno nu piešta. J. Jov.; Saulegrąžu / vejuota lauka / juodvarniai neša / iš aukso rému. A. Churg. (eil. „Paveikslai“); Už Van Gogo geltono saulegrąžu lauko, / už Pikaso veidu [esančių dalyku]], kuriuos žinom gerai, / mums norètu neleisti pamatyti $<\ldots>$ / drobès rèmu kampuoti griežti aptvarai. V. Reim.; Tu [mama,] stovi darže / Auksinį žiedq apsikabinusi / Nuotraukoje J. Jov.

Dovanoti skirta ir (arba) laikoma rankoje saulègrąža - dèmesio, meilès artimui ženklas: Trečia [saulègrąžą] laikau ant delno / Ir dovanoju Tau... O. Bal.; Viena saulègrąza - motinai, / Kita saulegrąža - tèvui, / O trečioji - skaitytojui. J. Jov. Žiedai nerealybèje, kurią įvardija tokie abstraktai kaip pasq̨moné, siela, beprotybè, žymi kūrybinę potenciją, aktyvią jausmų ir vaizduotės veiklą (perkèlimo pagrindą žr. skyriuje „Geltonos spalvos simbolika ir žydejjimo metaforos"), pvz.: saulegražzos žydi ir žydi, / pasqumonejj, po vandeniu, po žeme L. Sut.; Van Gogas! / Kovos beprotybejj / Saulegraž̌u ordinai žydi! B. Mack.; plg. dar ekspresyvesnius ,tikres- 
nių“ - apčiuopiamų augaviečių pavadinimus Vytauto Rudžiansko eilèraštyje: Saulegrąža žieda sukrauna / Garsiojoj Van Gogo ausyj. / <..> Saulegrąžos žiedas nusvyra / Garsiajam van goge Ausies...

Saulègrąžos atskirtị ir nutolimą nuo žmogaus rodo 'tuštumos' semą turintys daiktavardžiai dykuma, dykvietè, skurdybè, erdvé, laukas, statybvietè, iš dalies ir kalno viršūne, pavartoti 4 eilèraščiuose, pvz.: saulegrąža kūnas jos gręžès / dykumos erdvejje ị boluojančia saulę G. Ciešk.; Švietè soduos paskutiniai obuoliai- / Ir dvi saulègrąžos tuščiam lauke tarytum strazdanos. O. Baliuk. Augavietę, kur žmonès gali lankytis, bet nesilanko, galima laikyti keista: Atëjome j keista vieta čia nebuvo lèbauta / tik saulègrąža suko ratus K. Nav.

Saulègrąža esti su žiedais šviesiuoju paros metu šiltąji sezoną: juos būna išskleidusi nuo ryto iki vakaro, nuo vasaros vidurio iki ankstyvo rudens; apie tai kalbama 12-oje eilèraščiu, pvz.: Viena gražu, ankstu ryta, I Saulei patekejjus, / Mes išvydom nematyta / Vaizda pakelëje. / <...>Visas visas horizontas / Saulemis pražydo R. Petr.; [vakare] saulègražza <...>/ Užgęsta, nešasi tamsa jos žieda. J. Lin.; Juk saulègrąžu vasara trunka / Ligi pačio auksinio rudens. V. Rud. Žiedai aktualizuoja aktyvųji paros laiką ir gamtinio ciklo brandos tarpsnị - vasara.

Taigi saulègrąžos žydi žmogaus gyvenimo ir išgyvenimo metu - kalbètojo erdvèje ir laike (apie šią kategoriją žr. Апресян 1986, 281-285).

Vaizduojamojo objekto kiekis. Poetų žvilgsnis krypsta i pavienę saulègrąžą - pirmiausia ị jos žiedyną, didesnę ar mažesnę saulègrąžų grupę ir žemès plote augančių saulègrąžų visumą. Tokie stiebo dalių pavadinimai, kaip žiedynas, žiedas ar žiedlapis, eilèraščiuose reti, paprastai jų vietoje vartojamos metaforos (jas žr. skyriuje „Dydžio ir formos ypatybės raiška“).

Poetams dèmesį sutelkus ties atskiru žydinčiu augalu, nuosekliai vartojamos fitonimo saulègrazža vienaskaitos formos, ju - 65, pvz.: nubusdavau tarsi nokstanti sau lègraža ir paukščiai / lesdavo mano akis V. Blož.; Saulègražza, linguok, / Saulègražza, žydèk! P. Drev.

Rasti 3 pavyzdžiai, kuriuose vaizduojami keli augalai: du, trys arba tiksliai nepasakytas mažas kiekis, reiškiamas daiktavardžiu grupele, pvz.: Bus eilinis eiliuotas ruduo, / bus poetas, palinkęs prie stalo, / ir ant stalo saulègrąžos trys / antrarūṣ̌ soneta skaitys. A. Veikn.; Žydintis darželis, <...> / kelios rausvos piliarožès, smulkūs žolynai, auksiniu / saulègrąžu grupelé. N. Mil. Dar 2 fragmentuose daiktavardžiai tuntas 'didelis būrys, minia, 
pulkas' (DLKŽ ${ }_{7}$ 861) ir jo sinonimas minia aktualizuoja didesnị neapibrèžtą drauge augančiu saulègrąžu skaičių: [saulègrąžu] tuntas geltongalvis / pastojo keliq man A. Churg. ir Kaip artinosi tyliai, nekaltai / saulegrąžu minia, kaip tvieskè saulè! G. Ciešk.

Daug saulègrąžų žymi 59 pavyzdžiuose pavartotos daiktavardžio saulegrąža daugiskaitos linksnių formos, pvz.: Miesto pakraščiuos / Maži namukai. / Saulègražzos. / Piliarožès. / Jurginai. P. Drev.; vyzdžiai prasiplečia / iki van Gogo saulègrą̌u dydžio V. Bak.; Bet mes neaugom po tom saulègrą̌omis, / Nekvepavome ju šviesa. J. Jek. Labai svarbu, kad šitokiu būdu ìvardytą kiekini objektą lyrinis subjektas kategorizuoja ir vertina taip pat, kaip ir pavienius ar į grupes susitelkusius objektus.

Kitaip - kaip nedalijama visuma - vertinami žemès plotuose auginami augalai. Tokie augalai įvardijami dviejų daiktavardžiu junginiu: nusakomuoju kilmininku saulègrąžu ir augavietę reiškiančiu laukas (laukai), giraite arba sodai (rasti 9 pavyzdžiai, iš ju dažniausias, pasitaikęs 6 kartus, yra saulegražu laukas), pvz.: ir viduryje saulègražzu lauko sustojome H. Baub.; Pasišiaušęs stogas / lyg debesis saulègrąžu lauku linguoja V. Brenc.; Jie ieško ramybès saulègrą̌̌u giraitèje <...> Jie tiki / kad bitès pildo Ju valią ir saulegrąžos / žydi tik Jiems V. Rudž. Šiuo raiškos atveju saulègrąžos nèra veikejjos, jos - veikiančios gyvos būtybès fonas, taigi atlieka scenografinị vaidmenị.

Saulègrąžų kiekis lemia daiktavardinių metaforų poezijoje pobūdị. Identifikuojant atskirus augalus ar jų grupę, metaforizacijos pagrindas esti formos ypatybė, o nedalijamas, neskaidomas objektas - masyvas tapatinamas su tikrovès realijomis, kurios neturi apibrèžtos formos: gali plisti, sklisti erdvejje.

Galẻjimo judèti ypatybè. Poezijoje aktualizuojamas saulègrąžos stiebo siūbavimas, lingavimas arba jo pusiausvyra, žiedo sukinèjimasis: kilimas, svirimas, krypimas ị šoną, taip pat kraštinių žiedų išsiskleidimas ir susiglaudimas, plazdejjimas vejjyje ir byrejjimas. Apie tai kalbama 44 eilèraščiuose.

Saulègrąžų atliekamą veiksmą žymi būdvardis rami ir veiksmažodžių formos siūbuoja, siübavo, linguok, svyruoki, suko ratus, pasisuka, atsisuktu, gręžès, gręžkis, gręžiodamasi, nusigręžè, nusigręžia, atsigręžus, palinksta, pasviro, kyla, nuëjo, artinosi, grūmoja, nori užkapot, begaudo spindulius, melsčiaus; augalai taip pat tiesia kaklus, supo, kraipo, kelia, svarina ir nudelbia 
galvas, linksi galvomis, atsigręš veidu, grąžo rankas, suka žvilgsnị, būna nuleidę galvas, nuleistom galvom, iškèlus ir gręžus veida, pvz.: ra mi saulegrąža, nokstanti / nesugrąžinamos tèviškès tuščiuose laukuose N. Mil.; Žiūrèkite, / Kaip <...> / Saulegrąžos pasisuka j saulę... J. Nekr.; Mažoji Saule, / Tu grąžai rankas, / Gręžio da masi i savo didžiosios globëjos / Judëjimo trajektorija, / Buvimo grąžtas ịsuktas, / I tavo gležnq kūnq T. Marc.; tik saulègrąža suko ratus ir siūbavo vejjyje K. Nav.; Ji tylomis nuèjo - / saulègrąža gelsva / su džiūstančiais vainiklapiais / tik stiebas vienakojis / ir geometrija / juodu viniu galvučiu J. Jek.; Saulègrązos / (kaip iš van Gogo drobès) / grūmoja man, / lyg būčiau aš kadais / iš pasaly / Saulèpatị nudobęs, / jos nori užkapot mane kardais, / bet ju neturi A. Churg.; Saulègrąžai darže paskaudo laibq kaklq, / begau dant spindulius, kol saulè, kol diena... V. Reim.; Noréčiau gimt saulègrąža - / Ryta aš melsčia us liepsnojančiam dangui B. Aug.; žalio indenniško kraujo gèlè, / lyg išdygus iš Vilniaus baroko, / supo kilmingaja galva aukštai J. Vaič.; Toli akordeono eisena, tačiau / Saulegrąžos dar linksi galvomis i taktą. A. Mas.

Saulègrąžos žiedynas, vadinamas ir galva, veidu, taip pat juda: siūruoja, nusileido, svyra, nusvyra, nusviro, gręžiojas, pvz.: Auksinis saulegražos žiedas - / vakare siūruoja ir tviska - - B. Aug.; daugiau už mane mat išmano / todèl ir gręžiojas gal - va E. Miež. ${ }^{7}$ Kraštiniai žiedai, vadinami graižu ir akimis, lenkiasi į vidų ir, saulei pašvietus, atsitiesia: susiglaus, merkiasi, verési, kvatojas $^{8}$, virpa vėjyje, nukrinta: plevésuoja, plaikstosi, graibo saulę, slenka ir leidžias, pvz.: Iki vakaro gilaus / Aukso graižas susiglaus. $\mathrm{N}$. Nav.; vérési [saulègražos] akys regédamos / savo auganti senstanti kūna D. Zelč.; Lauko saulès pasiutę kvatojas A. Dapk.-Puk.; Jos [saulègrąžos] gelsvi plaukai / Slenka vejyje / Ir leidžias B. Aug.

Saulè, ị kurią krypsta žiedynas, poezijoje gali būti ịvardyta kontekstiniais sinonimais: po kartą aptikti šviesa, saulelydis, gaisas, vakarai, dangus (be konteksto paminèti daiktavardžiai reiškia saulès funkciją, šio dangaus

Autorinès rašybos gal - va suteikia dvejopą minties perskaitymo galimybę: galva gręžiojasi ir ji gal todèl va gręžiojasi, kad daug išmano.

8 Kvatojimas, kaip ir kapojimas, meldimasis atliekami energingai, su didele fizine ar dvasine jèga, kurią rodo tam tikri lengvai atpažįstami kūno dalių, ypač rankų, judesiai. Taigi identifikuojant kalbamuosius veiksmus judejiimo požymis yra labai svarbus, nors žodynuose jis paprastai nutylimas, plg. kapoti 'daug kartų kirsti, kertant atskirti' (DLKŽ 285), 'dažnai kirsti, pjauti, genėti; čaižyti' (LKŽe), kvatoti 'balsu juoktis' (DLKŽ ${ }_{7} 348$; LKŽe), melstis 'kalbèti maldas, kreiptis maldomis ị Dievą ar šventuosius' (DLKŽ ${ }_{7}$ 392). 
šviesulio leidimosi vietą horizonte ir atspindị, apskritai būnamąją erdvę), pvz.: Tiesia jos [saulègrąžos] kaklus i šviesq / Ir galvutes kelia. R. Petr.; nusviro i vakarus mano / saulegrąžos supergalva E. Miež.; Saulegrąžos $i$ rausva gais q žiūri A. Churg.; Saulégrąža žiūri i d angu, / Kol nukrenta visos akys. A. Lyv. Tamsiuoju paros metu saulès vietininkas danguje yra debesys: $O$ aš [- saulègrąža] - i debesis iškèlus veidq - / Stebéčiau, kaip <...> keliauja / Procesija žvaigždžių B. Aug. Šviesomègio augalo nusisukimas nuo saulès, aišku, negalimas: surinktuose pavyzdžiuose apie tai nekalbama.

Saulègrąžos žiedo krypti gali reguliuoti saulè: Saulutei patekëjus / Saulegraža pražysta, / Jai saule rodo keliq / Ir kreipia jos galvelę. G. Al. Saulei suteiktas Dievo galios požymis liudija archajiškąją pasaulèvoką: tradicinėje kolektyvinèje kultūroje visi dangaus kūnai suvokiami kaip gamtos ciklo reguliuotojai, pasaulio valdytojai ir tvarkdariai (apie kitokius sudievintos saulès darbus poezijoje žr. Kazlauskaitė 2005, 48). Beje, pirmykštės sąmonès elementus, kuriuos formuoja ir perduoda kalba, etnolingvistai pripažįsta labai svarbiais ir siūlo vadinti šalia verbalinio esančiu (przy-językowy) kontekstu (Bartmiński 1996, 11).

Poezijoje žiedynas krypsta ir ị žmogų. Pabrezžtina, kad ị žmogų ne tik atsigręžiama, bet ir nuo jo nusigręžiama, plg. Marcelijaus Martinaičio eilèraščio „Šiandien pajutau...“ fragmentus: Šị ryta / nu sigr rę̌é saulegrąžos / ir nepastebëjo manęs aguonos, / nepakalbino žole ir Bijau net pašaukti saulègražz - / atsigręš j mane vaiko veidu / ir neturésiu kq pasakyti. Veiksmo objektas žmogus paprastai įvardijamas asmeninio įvardžio aš formomis tokie pavyzdžiai 4. Dar viename eilèraštyje, Jono Liniausko „Matau, vaikai pro langą mums pamoja“, saulègrąža vaizduojama besirenkanti pasitenkinimą, saugumą keliančius dalykus, atsisakanti gyvenimo iššūkių, sunkumų. Ji nusigręžia nuo pavojų nebijančio jauno keleivio ir apskritai neramaus gyvenimo būdo, kelio: Ir, gavus diena, skaisčia ir malonia / Ji užkabori susiranda lyg čigonè, / Nusigręžia nuo kelio ir praeiviu. Plg. dar vieną fragmentą: Saulegrąžu didžiulès aukso akys žiūri ị saulèlydị - / aprauda paukščiu nesuprantama kelionę $\mathrm{H}$. Nag.

Judèjimo nebuvimą žymi 'regèjimo' veiksmažodžiai - ju 10: žiūri, regédamos, spokso - šis žodis žymi ir regèjimo organo didumą, stebéčiau, nemato, skaitys, pvz.: Nuskrenda žiežirbos, / spokso saulegrą̌zu ratai, / net vanduo sukasi. A. Pilv.; Mama, jos tyliai siūbuoja ir mūsų nemato. D. Duob. Sustingsta - žiurkso ị saulę atsisukęs žiedynas. 
Metaforiniai veiksmažodžiai, akcentuojantys galimybę judèti, rodo saulègrąžos ir gyvos būtybès sąsają.

Dydžio ir formos ypatybè. Poetų žvilgsnị traukia neịprastas saulègrąžos stiebo ir žiedyno dydis, sunkiai aprèpiami saulègrąžų plotai (9 pavyzdžiai). Objekto statinị matmenị tiesiogiai reiškia būdvardžiai aukštas, didžiulè: Kaip plevésuoja ji [vèliava 'žiedyno skraistlapiai'] / Saulegrąžu aukštam stiebe. O. Bal.; ant kalno viršūnès augo didžiulè saulègrąža H. Baub. Stiebo aukštị, artimą žmogaus ūgiui, rodo daiktavardinès metaforos moteris, mama, karaliene, jaunamartè, mergaitè, pvz.: Saulègrąžu aprištos galvos lyg moterų, / vidurdieni ravinčių daržą. Z. Maž.; Saulègrąža lyg karalienè kelia savo šviesia galvą. L. Reif.; Ten lyg jaunamartès drovios kraipo saulegrazžos galvas. V. Reim.; Mergaitè geltonais saulegrąžos plaukais ir veidu - / Saulès niekuomet nemačiusi saulègrąža - / Padejo man ant stalo duonos ir vandens. A. Nyk.-Nil. Apie tai, kad stiebas ypač aukštas, iškilęs į dangų, kalba daiktavardis milžine: Daržo milžinès kepuré / I saulutę nuolat žiūri. N. Nav., ir dviejų eilèraščių, turinčių toki pat pavadinimą „Saulègrąža“, fragmentai: Plačiabryle saule virš namu J. Vaič.; Aš pakilau saulegrąža ị saule L. Žitk. Saulègrąžos praauga žolynus, pvz., Gręžkis i saule, saulegrąža, / vëjy praaugus gèles. A. Vas., ir vešlumu, stotu primena medžius ar krūmus. Panašumą iškelia augavietes žyminčių metaforinių junginių antrasis dèmuo giraitè, sodas (žr. skyrių „Vaizduojamojo objekto kiekis“) ir sužèlusius krūmus įvardijantis brūzgynas. Tokių pavyzdžių - 10, pvz.: Saulègraž̌u soduos pabunda ir gieda strazdai. H. Nag.; brūzgynuose saulègrąžu lauko / tūpé paukščiai. J. Jek.

Išskirtinę žiedyno apimti 5 kartus pabrèžia būdvardžiai didelis ir didžiulis, dèmuo super, sujungtas su kūno dalies pavadinimu galva (ir pasakantis, kad toji dalis viršija ịprastą galvos dydị), o neribotą saulègrąžų laukų tąsą erdvèje - veiksmažodis driekiasi ir daiktavardis horizontas, pvz.: dar aš regiu auksalapi didžiulị jos [saulègrąžos] žiedq / dulkèta ir giedra J. Vaič.; Kiek aprèpia, kiek užmato / Akys mūsų žydros, / Visas visas horizontas / Saulemis pražydo. R. Petr.

Didelis saulègrąžos žiedynas, ypač brandinantis sẻklas, vertinamas kaip sunkus - 7 eilèraščiuose užsimenama apie jo svorị ir (arba) dèl svorio ị vieną pusę krypstantic stiebą, pvz.: Aš - tavo kaip tas ant lauko akmuo, / Kaip saulegrąžos saule, apsunkus nuo vaisių... S. Drab.; Saulegrąža / svarina sunkia galvą... / Oi, dar ir drugelis nutūpè! M. Val. Žiedą lenkia 
prinokusios sẻklos, rasa, lietus, aplink šèliojantys ir nutupiantys vabzdžiai, paukščiai - apie tai kalbama 14-oje fragmentų, pvz.:A psunkę sèklomis, saulègrazžos nudelbia galvas A. Mas.; Mano / peteliškè / plevena / aplink prinokusią / sauleggrąžos galva. V. Dašk.; $O$ ant saulegrąžu supos ramiausiai / Paukštukai. H. Čigr. Skraidantys gyviai veikia 10 pavyzdžių.

Žiedynas ir atskiri jo žiedai, žvelgiant iš viršaus, yra aptakūs, išgaubtos formos, todèl poezijoje paprastai asocijuojami su prototipiškai apvaliomis realijomis, plg. Išmokyk saulę / žiūrèt iš saulégrąžos / a pvalia galia. A. Pilv.

Didžioji tikrovès objektų grupè - gyvos būtybès kūno dalys ir apdarai, viršutinès kūno dalies atributiniai papuošalai. 35 kartus 'saulègrąžos žiedų' reikšme pavartotos metaforos galva, akys, veidas, strazdanos, plaukai, blakstienos, skutu sijonas, ordinai, karūna, kepuré, pvz.: Vèl karūnuotos saulègrąžu galvos / svyra žemyn. / Sako, vasara gęsta... R. Lunsk.; Ryta aš melsčiaus liepsnojančiam dangui / Aušru nubudusiom a kim / Virš mano kaimo--B. Aug.; Saulegraža giedru moters veidu - / saulès skutu sijonas plaikstosi vëjy... G. Din.; Ir man auksinius plaukus / Tingūs vëjai kedentu B. Aug.; skinu / Anu naktu saulegrąžas / blakstienomis įsaulintom. O. Baliuk.; Saulegražž ka rūnos tuoj liepsnos. V. Šobl. Vyrauja įvardijimai galva (15 kartų), akys (7) ir veidas (4), nes saulègrąžos žiedynas ir viršutinè kūno dalis panašūs ne tik forma, padètimi, bet ir bendrais 'judejjimo (judinimo)', 'spalvos' požymiais. Šiuc metaforų dažnumas patvirtina, kad saulègrąžą labiausiai apibūdina jos žiedyno - galvos, veido sūkis ir įdėmus žiūrëimas ị saulę (ar ją pakeičiantị žmogų). Beje, daiktavardis veidas siejamas su veiksmažodžiu vei(z)detti 'žiūreti, ieškoti' (DLKŽ 7 916), abu žodžiai kildinami iš ide. šaknies *ư $(e) d i-$ 'pastebèti, matyti' (žr. Sabaliauskas 1990, 16).

Nurodytos daiktavardinès metaforos saulègrąžą apibrèžia kaip žmogų, moteri. Išimtis -2 pavyzdžiai, teigiantys kalbamojo augalo ir katès, taip pat paukščio paralelę. Vienas jų, būtent saulegrąžos akys katinu žiūri A. Dapk.-Puk., primena, kad žiūrèjimas įbedus akis, kitaip tariant, akių judesių nebuvimas, ypač būdingas laimikio tykančiai katei. Kitas pavyzdys Ji meta žiedlapi, o žiedlapis kaip paukštis - / Vedlys vaikams parodo vejju kelia J. Lin. aktualizuoja nudžiūvusius žiedlapius ir paukščius suvokiant lemiamą 'judejjimo oru, skridimo’ požymį.

Konceptualiąją metaforą SAULĖGRĄŽA yra GYVA BŪTYBĖ sudarančių nominatyvinių daiktavardžių sąrašą papildo epitetai. Saulègrąžą arba jos žiedą 
apibūdina lyg iš baroko [laikų], kilmingoji, karūnuota, plačiabrylè, paklaikęs, dantytas, pasiutę, džiaugsmingas, linksma, o žiedų spalvą įvertina karališka, beprotiškas, pasiutęs.

Antra realijų grupè - žmogaus ūkinio gyvenimo reikmenys, daiktai. I reikmenu pavadinimų sąrašą patenka 10 kartu pasitaikę tauré, lèkšté, puodas, paplotis, ratas, pasoste 'sèdynè (vežime, staklèse ir kt.)' (DLKŽ 7 516), pvz.: Lyg taurès auksiniais dugnais / Saulegrąžos kyla iš daržo. P. Širv.; saulègražos galva kaip skraidanti / lèkštè prie lango nusileido E. Miež; Juk ne saulegražă - / Jos dideli geltona puoda / Tarsi ant laužo užstatai. O. Bal.; galva nulinko kaip saulegrąžos paplotis / nors graibo saulę dar vainiklapiais. E. Miež. I sąrašą įtrauktinas ir dar vieno daikto - vèliavos pavadinimas, nes plevėsuodama saulegrą̌ž aukštam stiebe, vèliava ịgyja tokią pačią gaubtą - bangos formą. Tam tikrą formą, tiesa, ịprastai kertètą, turi ir žibintas, langas, veidrodis, pvz., Nuleistom galvom / Perdegę saulegrąžu / Žibintai M. Val. Pastarieji trys daiktai turi organišką ryšš su šviesa, todèl rastų vietą ir trečiojoje grupejje.

Prie maisto produktus pavadinančių daiktavardžių šlyja po vieną kartą pasitaikę būdvardžiai šviežias, svaigus ir šiltas. Tai konceptualiosios metaforos SAULĖGRĄŽA yra BUITIES REIKMUO reprezentantai.

Trečią apčiuopiamų lanko pavidalo objektų grupę sudaro šviesos šaltiniai ir ju priklausiniai. Rasta 15 tokios semantikos metaforų: saulé, laužas, liepsnele ir nimbas 'šviesus ratas, spindesys aplink įkaitusį daiktą', pvz.: Saulegrąžu saules surinkusios / Vasaros rankose miršta daigai-- B. Aug.; Plačiabryle saule virš namu - / ryški kaip nimbas. J. Vaič.; Saulègrąžos liepsnele nebyli, / Susirenki žodžius - nebeištarsi. V. Bak. Analizuojamuosiuose eilèraščiuose daugiausiai kartu (12) saulèg rąžos žiedynas turi metaforini saulès vardą. Daiktavardis saule kartais tikslinamas epitetu: pavartoti žemiška, žemès, lauko, maža, mažoji, be to, palyginti su dangaus kūnu, sąlyginis mažumas gali būti reiškiamas deminutyvinėmis priesagomis - aptikta -elè, pvz.: Kaip simboli žemiškos saulès - / Jos žemei kraujuotai nešu. V. Rud.; Džiaugias bitès ir kamanès / Mažu sauliu jūra, / Nardo, siaučia tarp žiedelių, / Saulei odę kuria. R. Petr.; Argi gali būt pasauly / Tūkstančiai sauleliu? R. Petr. Akivaizdus ryšys tarp saulès ir saulègrąžos matyti Henriko Nagio eilèraštyje „Pradžios mokykla kaime“: jo [popierinio paukščio] stiklinès akys / atspindi abejingai mirusia saulègrą̌ose saulę. Reinkarnacija yra archajinès pasaulèvokos elementas. 
Prie šviečiančių ir spindinčių objektų pridera snaigè: Jos [saulègrąžos] gelsvi plaukai / Slenka vëjyje / Ir leidžias, / Kaip geltonos snaigès -B. Aug. Daiktavardis snaigè reiškia 'atskirą sniego žvaigždutę, sniego kąsneli (sningant)' (DLKŽ $\check{z}_{7} 717$ ). Sniegas lietuvių pasaulèvaizdyje, kaip rodo žodynų definicijos, yra prototipinis baltumo skleidejas: baltas, -a 'kuris sniego spalvos, visai šviesus“ (DLKŽ ${ }_{7} 71$ ), arba, tiksliau kalbant, vienintelio achromatinių spalvų atveju realizuojamo komponento šviesio reprezentantas. (Apie rega suvokiamas spalvos charakteristikas: šviesos toną, švieși ir sotị, ir jų raišką žr. Апресян 1974, 9 ir ten min. lit.)

Šviesos skleidejjus tiesiogiai žymintys daiktavardžiai saule, laužas, liepsnelè, nimbas, snaigé reprezentuoja konceptualiąją metaforą SAULĖGRĄŽA yra ŠVIESOS ŠAlTINIS. Dar vienas šios metaforos atstovas - porą kartų pavartotas būdvardis giedras.

Žydinčių saulègrąžų augavietès poezijoje tapatinamos ir su erdvinėmis, aiškių ribų neturinčiomis realijomis: skysčiais ir dideliais vandens telkiniais, ugnimi, šviesa. 7 kartus pavartotos metaforos rašalas, šviesos marios, jūra, ugnis, gaisras, spinduliai, pvz.: Driekiasi šviežias geltonu saulègrąžu rašala s. A. Bar.; Vèl kalbate apie saulegražzu vidudienius, / Ištvinusias / Šviesos marias --- R. Ket.; Saulégrąžu ugnis išsprogus. A. Verb.; Geltoni spinduliai. / Juoda praraja. / Tai tik saulegrąža. V. Jurg. Dar du, abstraktesni, daiktavardžiai, potvynis 'periodinis vandens pakilimas' (DLKŽ 578) ir miražas 'optinis reiškinys, kai matomi už akiračio esantys daiktai' (DLKŽ ${ }_{7} 402$ ), taip pat būdvardis ištvinusios, žymi tikrą ar tariamą žiedų pagausẻjimą tam tikru metu: Saulégrąžoms ir laisvè, ir nelaisvé-Saulè. / Ir mano sieloje ṣ̨̌ ryta - aukso potvynis... O. Baliuk.; toks pasiutęs geltonas miražas A. Dapk.-Puk.

Atkreiptinas dẻmesys, kad šviečiantys ar švytintys objektai perteikia žiedų spalvos ypatybę.

Spalvos ypatybè. Daugiau kaip pusejje surinktu poezijos pavyzdžiu iš viso 75-iuose - kalbama apie saulègrąžos žiedų spalvą. Tam pirmiausia pasitelkiami tiesiogiai spalvą žymintys šaknų gelt-, rud-, juod- žodžiai, bet dar dažniau renkamasi ekspresyvesni ypatybès ịvardijimo būdą - metaforas.

15 kartu pavartoti kamieną gelton- turintys žodžiai: veiksmažodis geltonavo, būdvardis geltonas, $-a$, iš jo padaryti prieveiksmis geltonai ir abstraktusis ypatybės pavadinimas geltonis, taip pat determinatyvinis dūrinys geltongalvis; dar 3 kartus pasitaike blankesnị atspalvị reiškiantis būdvardis 
gelsvas, -a, pvz.: Po langais geltonavo saulegrazžos... J. Butk.; Geltonos saulegrąžos - šiltos kaip tavo rankos. D. Duob.; Saulegrąžų laukai juodi ir nykūs. / Ir žiedlapiai gel to ni - jau kadais / Po kojom suminti. O. Baliuk.; tai ne beprotiškas saulegrąžu gel to nis A. Jon.; Svyruoki ị šalis - / Nuo vasaros gelsva. P. Drev.

15 kartų aptikti apibūdinamieji žodžiai aukso, auksinis, auksalapis ir nuauksintas žymi tą pačią spalvą, nes būdvardžio geltonas, - $a$ definicija - 'kuris aukso spalvos' (DLKŽ $\left.{ }_{7} 172\right)^{9}$, pvz.: Bet galva jos už pastanga atkakliq / apvainikavo aukso karūna. V. Reim.; Merkias saulègrąžu akys auksinès, / Saulè išblèso. B. Lin.; saulès gèlè, šitaip permainingai / gręžus nuauksinta veida pro dulkių debesis J. Vaič.

Geltonavo ir metaforinių veiksmažodžių patekèti, švytèti, tviskèti, šviesti, tvieksti, (su)spindèti, jsaulinti, (per)degti, liepsnoti, užgesti asmenuojamosios ir neasmenuojamosios formos (jų 17) tiesiogiai priklauso ‘šviesos' semantiniam laukui. Jos informuoja apie laikotarpi, kai žiedai yra išsiskleidę. Prieš patekant, pradès spindèti, suspindètu rodo paskutines akimirkas iki žydèjimo pradžios, pvz.: Kregždès lietú pranašauja. / Prieš patekant saulègražoms laukuos. V. Rudž.; Ryta eisiu pažiūrèti, / Kaip jis [graižas] vèl pradès spindèti. N. Nav. Švyti, tviska, švietè, tvieskè, degè, liepsnos, šviesdama, švietusi, degančius, isaulintas konstatuoja intensyvaus žydejjimo tarpsnị dabar ar praeityje, pvz.: Saulegrąžos prietemoj švyti. D. Duob.; Joms [mergaitèms] tvieské / saulègražu saulès pasosté, A. Mas.; Tai saulègraža degè G. Ciešk.; Geltonai / saulègrąža liepsnos. A. Churg.; Palinksta, visa šviesdama, / Saulègrąža. Saulè. Mama. J. Vaič.; Ir birtu spindinčios padangiu vyšnios / I mano degančius geltonus plaukus. B. Aug. Užgęsta, perdege patvirtina žydejjimo - buvusio ryškumo pabaigą, pvz., saulègrąža, ramiai kaip langas švietus, / Užgęsta. J. Lin. Maksimalų ryškumo laipsnị žymi veiksmažodžių tviskèti, spindèti, degti ir liepsnoti formos (žr. Крылова 2001), vadinasi, saulègrąžų žiedų spalva aplinkoje išskirtinė. Varginamą ryškumą rodo dviejuose Onès Baliukonès eilèraščiuose aptikti prieveiksmiai žiauriai, aitriai: paliko vasara - taip žiauriai / Mums švietusi saulè-

9 Kad spalva laikoma esmine aukso ypatybe, rodo indoeuropiečiu kalbose įsigalèję naujesni metalo pavadinimai, kamieno * $g^{[/ h} e l-$ 'geltonas', 'geltonai žalias' žodžiai: s. ind. híranya-, av. zaranya-, go. gulp, s. angl. gold, la. zelts, s. sl. zlato ir pan. Pirmykščiai kamieno *Haun-s- / Hü-os pavadinimai išliko nedaugelyje kalbų: lotynų - aurum, prūsų ausis, tocharų - wäs, yasa ir, žinoma, lietuvių - auksas (<*aus-kas) (Гамкрелидзе, Иванов 1998, 713-714). 
gražž žiedais („Saulèg rąžoms ir laisvè, ir nelaisvè - Saulè..."); taip aitriai geltona ir vieniša... („, buvo tik šuolis per prarają...").

Abstrahavus spalvos ypatybę, 'saulègrąžų žiedų' reikšme imamos vartoti metonimijos. Be minèto geltonis, poezijoje 11 kartu pavartoti ochra 'geltoni gamtiniai dažai' (DLKŽ ${ }_{7} 460$ ), dažai 'dažomoji medžiaga' ( DLKŽ $_{7} 112$ ) ir dažas 'spalva' (LKŽe), šviesa 'kokio nors natūralaus ar dirbtinio šviesulio ar spinduolio skleidžiami ar atspindimi spinduliai (elektromagnetinès bangos, jų energija)' (LKŽe) ir spalva 'šviesos tonas, dažas' (DLKŽ 7 720), blyksniai 'šviesos spindulys' (LKŽe), pvz.: saulegrąžu ochroj - branda. V. Žil.; Saulegraža. Saulè. Mama. / Aplinkui tokia ramuma. / Taip šilta. Ir juokias dažai. J. Vaič.; Atskriejo balti milijonai drugiu i karališkq / saulegrąžos šviesa. G. Ciešk.; Te dirbtuvès keturias sienas / Užtvindys auksine [saulègrąžu] spalva! V. Rud.; Vien tik vèlyvos / gèlès darželio, / vien tik saulègrąžu / blyksniai geltoni. A. Churg. Metonimijos, reiškiamos daiktavardžiu abstraktais, pabrèžia esmines geltonos spalvos kokybines charakteristikas: tai gerai atmušanti saulès spindulius ir pagal šviesio laipsni achromatinei baltai beveik prilygstanti chromatinè spalva. Spalva yra šviesos reiškinys, todèl dažniausias abstraktusis daiktavardis, žinoma, yra šviesa. Jis pavyzdžiuose pavartotas 6 kartus.

Ryški saulès antrininkès saulègrąžos spalva, apibendrinus - šviesa, žmonèms yra maloni: džiugina - šildo, pagirdo sielą: 1 rudens diena pilka / saulegrąžu laukas. / Kaip šviesu! / Kaip geltona! <... / O, kaip noréčiau, / kad nusiminusių / soduose / saulègrąžu vëjai / prisètų. / Gal tada ir jie / i džiaugsma / atsigręžt panorètu, / kai saulegrąžos saulemis / po ju langais / suspindètu. S. Dzen.; Žmonèms tegu saulina veidus / Saulegrąžu sauliu šviesa! V. Rud.; saulegrąža taip nebešildo / kaip šilde prieš valanda M. Ras.; Saulègrą̌ă, švelnių žiedlapių šviesa / It saulètu lietumi mano siela pagirdyk... D. d'Erc.

Retais atvejais geltona žiedų spalva gali žymèti skausmo būseną - gedulą: ko gedi saulegrąžos? / stovi liūdnai / nuleidę galvas M. Val. Tiesa, akivaizdesnis skausmo rodmuo šiuo atveju yra poza (nuleidę galvas). Poezijoje gedulą žymi ir rudeni geltona tapusi medžių lapija (apie tai žr. Kazlauskaitè 2005, 48).

Tik 4 kartus surinktuose eilèraščiuose žodžiais juodas, juoda, rudas j̇degęs ir pajuodo nusakyta žiedyno vidurio spalva, pvz.: Vasara baigès - / Saulegrąžai pajuodo veidas. B. Aug.; I rudq ìdegusị veidq / Nuo vasaros 
kaitriu laužų - / Nutūptų rasos gaivinančios bitès. B. Aug. Bet neįmanoma pasakyti, ką tiksliai šios būdvardžių ir veiksmažodžiu formos perteikia: tamsesnị vidinių žiedų ar ir nokstančių sẻklų toną.

Kaip bebūtų, akivaizdu viena: suvokiant saulègrąžą relevantinè yra kraštinių žiedų spalva. Asociacijų eksperimentų rezultatai rodo, kad kai kuriose kultūrose, sakysime, ukrainiečių, šis augalas netgi pripažĭstamas prototipiniu geltonos spalvos skleidèju (žr. Залевская 1988, 41). Plg. šalies ir augalo sugretinimą pavyzdyje Sakydama, Ukraina, / Glostau saulégrąžos galvą. B. Baltr.

Geltonos spalvos simbolika ir žydejjimo metaforos. Aptikti 6 eilèraščiai, kuriuose saulègrąžos kalba, rašo, rodo, primena - kitaip tariant, komunikuoja su pasauliu, skelbia žinią. pvz.: Saulegrąžos gali daugiau / Pasakyt / Apie šviesq. S. Ged.; o svarbiausia-parašyti Tau šviesq D. Zelč. (eil. „Saulègrąžos malda“). Toji žinia, kaip nesunku suprasti, yra šviesa.

Šviesiausia chromatinè žiedų spalva perima visas su žmogumi ir saule (ugnimi) tiesiogiai susijusias reikšmes ir, išplètusi savo semantiką, igyja ženklo vertę: Saulegraža reiškia / Saulès grižima, / Meilès grižima... V. Rud. Viena saulegraža - vilčiai [pažymèti], / Antra-tikèjimui, / O trečioji-meilei. J. Jov.; užpernai augus saulegrąža $-/<\ldots>$ buvo tos vasaros simbolis J. Vaič. Taigi geltonai žydinti saulègrąža tampa siekių ir norų: svajonès, vilties, tikejimo, meilès, gyvenimo aistros - vaizdine metafora, pvz.: Vilties / Tuščiavidurei sauleggrąžai / Laiko kirminas / Pragręžia širdị-- B. Aug.; Būk saulegrąža man paprasta. / <...> Ir liepsnos nenumaldomos aistros, / Žemei vaisiu brandžiausiq jos duos. V. Rud., plg. Sapnai ir svajonès žydi / Kaip saulegrazzos - - B. Aug. Beje, kartais norai ir lūkesčiai apčiuopiami, nes netolimi, matomi horizonte. Juos ịkūnija vaiko, obels ir pan. vaizdiniai: Matau, ant kalno ji [saulègrąža], dabar už miško, / Dabar svajoné, vaikas, obelis ji. J. Lin. Obelis yra namų aplinkos, vadinasi, žmogui itin artimas medis.

I žmogų atsigręžusios saulègrąžos žymi trokštamą kūrybinị ịkveipimą: noras <...>: kad atsisuktu saulegrą̌os /: trumpas: kaip gurkšnis tuščio K. Nav., o neilgai trunkantis žydèjimo laikotarpis (vasara) signalizuoja energingą dvasios pasaulio vyksmą: aktyvią vaizduotę ir emociju pliūpsnius, su tuo susijusį kūrybiniu jègų antplūdị, patị kūrybos procesą ir apskritai gyvenimo pilnatvę, pvz.: Širdyje taip šviesu - / lyg žydètų sau- 
lègraža, / kai liepsnojantis dažas / vaizduotę užlieja V. Rudž.; Rašau ne laiškus, ne eilèraščius - skinu / Anu naktu saulègrązas / blakstienomis isaulintom. O. Baliuk.; Jūs, švarūs ir teisingi žodžiai, / Vèl kalbate apie saulégrąžu vidudienius. R. Ket., plg. Kada iš manęs jas [saulègrąžas] išskynei, išdeginai, išvogei? / Many kaip dykynèj dabar. O. Baliuk.

Kurdamas žmogus ịprasmina savo buvimą - įsiamžina: kas yra nenutrūkstantis / aš / kurio žydejjimas trumpas, supratau iš vyšnaičiu ir sauleggrąžu V. Blož., plg. Kaip tau [saulègrąža,] pavyksta <...> Grąžinti iliuzija, / Kad grožis - / amžinas T. Marc. Kūryba ne tik teikia pasitenkinimą - svaigina, ji neatsiejama nuo kančios: jo [žiedo] pirma dovana šis svaigus lyg nuodas geltonis. K. Nav.; Ejimas saulegrazžos link / Trapus ir skausmingas. I Jaučiame ramsti - Van Gogui buvo sunkiau. S. Eitm. Sielos balso besiklausantys, $\dot{i}$ šviesq besigręžiantys menininkai ne visada sulaukia visuomenès supratimo ir, juo labiau, pripažinimo: Poetas saulegrąža, / Saulegrąža poetas. / Veidu ị saule, / neatstoda mas - veidu $\dot{j}$ / saulę. S. Ang1.; O mūsų sielos kaip saulegrąžos - / Vis saulès linkui. / Ir šito noro nieks nesustabdys A. Kul.

Saulègrąžu poetinèje erdveje svarbi ne(pri)sitaikymo prie aplinkos, nesivaldymo, pamišimo, beprotybės tema. 12-oje eilèraščiu aktualizuoti Vincento van Gogo, vieno iš garsiausių tapytojų, biografijos faktai. Minimas Prancūzijos miestelis Arlis, kur jis išgyveno kūrybini pakilimą ir kur, paūmejjus depresijai, kaip manoma, nusipjovè ausị. Arlyje van Gogas atrado šviesias, itin ryškias spalvas ir nutape geriausius savo paveikslus, tarp ju garsiąsias „Saulègrąžas“. Du eilèraščiai: Vytauto Rudoko „Van Gogas. 'Saulègrąžos"“ ir Gražinos Cieškaitès „Sparnai van Gogui“", patvirtina, kad ryškus geltonas (van gogiškas) potejpis yra plačiai suvokiamo nerimo, atskirties, iškilumo, šviesos raiškos priemone ${ }^{10}:$ Diktorius $^{11}$. Prancūzija, galimas daiktas, susprogdins nedidelio pajegumo vandenilinę bombq. / Van Gogas. Aš svajoju ištapyti savo dirbtuvę pustuziniu „Saulegrąžų“ [epigrafas]. // Aš noriu

10 Plg. per asociacijų eksperimentus išryškèjusias geltonos spalvos konotacijas rusų, baltarusių, lenkų, ukrainiečių, vokiečių ir prancūzų kultūrose: 'išdavystë', 'atsiskyrimas', 'pavydas', 'neapykanta', 'pavojus', 'liga' (Залевская 1988, 43-45). Hermanas Pleijus, tyręs simbolines spalvų reikšmes viduramžiais ir vèliau, teigia, kad geltona spalva, ypač deriniuose su žalia, naudota bjaurumui, nepatikimumui ir negebejjimui remtis protu, emocingumui nusakyti; atsvara nelemtai geltonai - pozityvusis skaistusis saulès šviesos tonas (Pleij 2010, 112-115).

11 Kalbètoju ịvardijimus Diktorius ir Van Gogas autorius yra ne pabraukęs, bet išretinęs. 
išreikšt savo sielos / Virpèjimą. Svaigsta galva.; Saulègrąžu minia lydejo auštant / i paskutini guoli- - p paveiksla / vienin teli nepakartojamq tave. / <...> Pavirto spalvos, atspalviai sparnais.

Tyrimo apibendrinimas. Poezijoje susidèstęs ir po analizès išryškèjęs žydinčios saulègrąžos vaizdinys bendrais bruožais nusakytinas taip:

1. Saulègrąža yra pavienis aktyviai veikiantis tikrovès objektas. Tik dideli saulègrąžu plotai apmąstomi kaip beribè neskaidoma visuma; tokiu atveju augalu funkcija scenografinè - tai kitos gyvos būtybès veiksmo vieta.

2. Skiriamosios saulègrąžos ypatybès yra trys: gebejjimas judèti, dydis ir forma, kraštinių žiedų spalva. Skiriamosios ypatybès pagrindžia visus augalo vardus.

Saulègrąžos stiebas juda visomis kryptimis, žiedynas krypsta ị saulę seka ją ịdėmiu žvilgsniu, išsiskleidę skraistlapiai plaikstosi vèjyje, jie vakare susiglaudžia, ryte atsitiesia, o nuvytę ima kristi; kartais žiedynas sukasi ne į saulę, bet į žmogų. Saulègrąža iš kitų žoliu išsiskiria aukštu stiebu ir dideliu apvalios formos žiedynu. Žiedyną svarina rasa, vabzdžiai ir paukščiai. Suvokiant saulègrąžų visumą, masyvą, lemiama ypatybè - formos nebuvimas. Tiesiogiai ar metaforiškai ịvardyta spalva - ji skaisčiai geltona praneša, kad augalas žydi, todèl tai esminė ypatybė.

3. Saulègrąža asocijuojama su žmogumi, jos žiedynas ir ratu išsidèstę kraštiniai žiedai - su saule, viršutinėmis žmogaus kūno dalimis, prototipiškai apvaliais, išgaubtais arba (ir) atspindinčiais šviesą papuošalais, namų reikmenimis. Atskiri kraštiniai žiedai tapatinami su oru judančiais nedideliais objektais: snaigèmis, paukščiais, o žiedų visuma - su erdvejje išsklindančiomis, išplintančiomis realijomis: ugnimi, šviesa, skysčiais, tyvuliuojančiais vandens telkiniais.

4. Žydintis augalas žymi žmogaus gyvenamąją vietą: auginamas darže prie namų ar laukuose šalia kelių - jais einama ar važiuojama, nuskintas ar pasodintas laikomas kambaryje, teikiamas kaip dovana, atvaizduojamas meno kūriniuose. Žiedai žymi ryškiausius žmogaus gyvenimo ir išgyvenimų momentus. Iૃkurdinta žmoguje - jo pasąmonèje, sieloje ir pan., žydinti saulègrąža i̇gyja ženklo vertę, išreiškia vidinio gyvenimo intensyvumą: vaizduotės gyvastị, emocijų laisvę, kūrybinių jègų antplūdį, kūrybos procesą ir apskritai gyvenimą.

Žiedų spalva perima visas su saule (ugnimi, šviesa), žmogumi, skysčiais tiesiogiai susijusias reikšmes: geltonis vadinamas giedru, liepsnojančiu, ka- 
rališku, beprotišku, svaigiu, aitriu ir pan. Žvelgiant konceptualiai, geltoni saulègrąžos žiedai žymi plačiai suvokiamą nerimą, šviesą, iškilumą ir atskirtị - apibendrintai jègą, didybę.

\section{Cituotuc poetuc varduc ir pavardžiuc} sutrumpinimai
G. Al. - Greta Aleksandravičiūtè
S. Angl. - Stasys Anglickis
B. Aug. - Balys Auginas
V. Bak. - Vainius Bakas
O. Bal. - Ona Baliukienè
O. Baliuk. - Onė Baliukonytė (Baliukonè)

B. Baltr. - Birutė Baltrušaitytė

A. Bar. - Albinas Baranauskas

H. Baub. - Haroldas Baubinas

V. Blož. - Vytautas P. Bložè

V. Brenc. - Vytautas Brencius

J. Butk. - Juozas Butkus

G. Ciešk. - Gražina Cieškaitè

A. Churg. - Aleksys Churginas

H. Čigr. - Henrikas Čigriejus

A. Dapk.-Puk. - Antanina Dapkutè-Pukènienè

V. Dašk. - Valdas Daškevičius

G. Din. - Gynė Dineikaite

S. Drab. - Silvestras Drabavičius

P. Drev. - Paulius Drevinis

D. Duob. - Dalia Duobaitė

S. Dzen. - Stasè Dzenuškaitè

S. Eitm. - Stasys Eitminavičius

D. d'Erc. - Danielè d'Erceville (Girdenytè)

S. Ged. - Sigitas Geda

L. Gut. - Leonardas Gutauskas

J. Jek. - Julija Jekentaite

A. Jon. - Antanas A. Jonynas

J. Jov. - Janina Jovaišaite

V. Jurg. - Viktorija Jurgelevičiūtè
R. Ket. - Robertas Keturakis

A. Kul - Albinas Kuliešis

J. Lin. - Jonas Liniauskas

B. Lin. - Bronè Liniauskienè

A. Lyv. - Algimantas Lyva

R. Lunsk. - Rita Lunskienè

B. Mack. - Bronius Mackevičius

T. Marc. - Tautvyda Marcinkevičiūtè

M. Mart. - Marcelijus Martinaitis

A. Mas. - Antanas Masionis

Z. Maž. - Zita Mažeikaitė

E. Miež. - Eduardas Mieželaitis

N. Mil. - Nijolè Miliauskaitė

H. Nag. - Henrikas Nagys

K. Nav. - Kęstutis Navakas

N. Nav. - Nijolè Navikienè

J. Nekr. - Juozas Nekrošius

A. Nyk.-Nil. - Alfonsas Nyka-Niliūnas

R. Petr. - Rima Petrilevičienè

A. Pilv. - Algirdas Pilvelis

M. Ras. - Martynas Raseinis

L. Reif. - Lolita Reifonaitė

V. Reim. - Vacys Reimeris

B. Rib. - Bronius Ribokas

T. Rost. - Tatjana Rostovaitė

V. Rud. - Vytautas Rudokas

V. Rudž. - Viktoras Rudžianskas

L. Sut. - Liūnė Sutema

P. Širv. - Paulius Širvys

V. Šobl. - Violeta Šoblinskaitė

J. Švab. - Julija Švabaite

J. Vaič. - Judita Vaičiūnaitė 
M. Val. - Mindaugas Valiukas

A. Vas. - Auksè Vasaitytė

A. Veikn. - Aivaras Veiknys

A. Verb. - Algirdas Verba

D. Zelč. - Dovilè Zelčiūtè

J. Zdan. - Jonas Zdanys

V. Žil. - Viktoras Žilinskas

L. Žitk. - Leonardas Žitkevičius

\section{Literatūra}

Bartmiński 1996 - Jerzy Bartmiński (ed.). Słownik stereotypów i symboli ludowych, t. I: Kosmos, [cz.] 1: Niebo. Światta niebieskie. Ogień. Kamienie. Lublin: wydawnictwo UMCS.

DLKŽ ${ }_{7}$ - Dabartinès lietuviu kalbos žodynas: septintas pataisytas ir papildytas leidimas. Vyr. red. Stasys Keinys. Vilnius: LKI, 2012.

Gritènienè 2006 - Aurelija Gritenienè. Augalu pavadinimu motyvacija šiaurès panevėžiškiu patarmëje. Vilnius: LKI leidykla.

Kazlauskaitė 2005 - Rūta Kazlauskaitè. Rudens lapų spalvų raiška lietuvių poezijoje. Filologija: (Pasaulio vaizdas kalboje), nr. 10, 42-51.

Kazlauskaitė 2010 - Rūta Kazlauskaitè. Žydinčios aguonos vaizdinys lietuvių poezijoje. Filologija, nr. 15, 53-70.

Kazlauskaitè 2011 - Rūta Kazlauskaitė. Žydinčios vyšnios vaizdinys lietuvių poezijoje. Acta humanitarica universitas Saulensis, t. 13: Medis kultūroje, 440-455.

LF VI, 71 - Lietuvos TSR flora, t. VI. Vyr. red. A. Minkevičius. Vilnius: Mokslo leidykla, 1980.

LKŽe - Lietuvių kalbos žodynas, t. I-XX, 1941-2002: elektroninis variantas. Vyr. red. Gertrūda Naktiniené, 2005 (http://www.lkz.lt/startas.htm).

Pleij 2010 - Herman Pleij. Karminas, purpuras ir mèlis: apie spalvas Viduramžiais ir véliau. Vilnius: Aidu leidykla.

Sabaliauskas 1990 - Algirdas Sabaliauskas. Lietuviu kalbos leksika. Vilnius: Mokslo leidykla.

Smith 1993 - Michael B. Smith. Cases as Conceptual Categories: Evidence from German. R. A. Geiger and B. R. Ostyn (eds.). Conceptualizations and Mental Processing in Language (Cognitive Linguistics Research 3). Berlin, New York: Mouton de Gruyter, $531-565$.

Stambovsky 1988 - Philip Stambovsky. The Depictive Image: Methaphor and Literary experience. Amherst: The University of Massachusetts Press.

Vilkonis 2001 - Kęstutis Kazimieras Vilkonis. Lietuvos žaliasis rūbas: atlasas. Kaunas: Lututes leidykla.

Wagner, Radner 1974 - Geoffrey Wagner, Sanford R. Radner. Language \& Reality. A Semantics Approach to Writing. New York: Thomas Y. Crowell Company.

ŽŪE III - Žemès ūkio enciklopedija, t. III. Vilnius: Mokslo ir enciklopedijų leidybos institutas, 2007.

Апресян 1974 - Юрий Д. Апресян. Лексическая семантика: синонимические средства языка. Москва: издательство Наука. 
Rūta Kazlauskaitè

Žydinčios saulègrąžos

vaizdinys lietuvių poezijoje

Апресян 1986 - Юрий Д. Апресян. Дейксис в лексике и грамматике и наивная модель мира. Семиотика и информатика, вып. 28. Москва: ПИК ВИНИТИ, 5-33.

Гамкрелидзе, Иванов 1998 - Т. В. Гамкрелидзе, Вяч. Вс. Иванов. Индоевропейский язык и индоевропейцы: Реконструкция и историко-типологический анализ праязыка u протокультуры, ч. II. 1. Благовещенск: Благовещенский Гуманитарный Колледж им И. А. Бодуэна де Куртенэ.

Демьянков 1994 - В. 3. Демьянков. Когнитивная лингвистика как разновидность интерпретирующего подхода. Вопросы языкознания, № 4, 17-33.

Залевская 1988 - А. А. Залевская. Некоторые проявления специфики языка и культуры испытуемых в материалах ассоциативных экспериментов. Этнопсихолингвистика. Москва: издательство Наука.

Крылова 2001 - Т. В. Крылова. Лексика со значением отражения света. Труды Международного семинара Диалог' 2001 по компьютерной лингвистике и ее приложениям, т. 1: Теоретические проблемы (http://www.dialog-21.ru/Archive/2001/volume1/1_20.htm).

Маслова 1997 - В. Маслова. Лингвистический анализ экспрессивности художественного текста. Минск: издательство Вышэйшая школа.

\section{Rūta Kazlauskaitè}

\section{MENTAL IMAGE OF SUNFLOWER IN BLOOM IN THE LITHUANIAN POETRY}

\section{Summary}

The sum total of individual metaphors defining one fragment of the reality shows the specifics of thinking and feeling of the authors (and of the linguistic society, to which the authors belong), their abilities of the cognition of the world, principles of structuration. The present cognitive semantic research is meant to discuss, compose and evaluate the image of sunflower in Lithuanian poetry. The fragments of 115 poems, written by 68 Lithuanian poets, have been analysed.

In poetry most often visual features of the sunflower are emphasized: non-static position, yellow colour of ray flowers and the round form of inflorescence or the spread of plants in bloom in fields. All the indicated features is the basis of metaphorisation. In the poetry sunflowers perform three actions: swing, sway or bend, rise, turn the large inflorescence towards the sun or a person, and distinguish in the environment by the bright tone. The inflorescence bends downwards because it is heavy with seeds, moreover, it is weighed down by dews, butterflies, bees, and birds. 
Sunflowers grow near people's houses, usually in the garden, by the roads. In one or another case the place of growth is expanded: the plant comes into flower under water, under ground, in the subconsciousness, in the soul. Sunflowers open their individual ray flowers ("petals") in the daylight during the warm season: they bloom from morning until evening, from midsummer until early autumn.

In the poetry usually one or several sunflowers are depicted, more rarely the indefinite number of sunflowers in bloom is mentioned. A single sunflower is usually perceived as a human being, while the parts of the stem of this plant - as the parts of human body or decorations, handicraft ware. Sunflower is called a woman, girl, garden giant, queen; its inflorescence and ray flowers situated in a circle - a head, face, eye, hair, eyelashes, freckles, cap, crown, medal, skirt, glass, plate, pot, cake, torch, pane, mirror, wheel, box-seat; separate falling ray flower - bird, snowflake. Because of the unity of colour and form the parallel between this plant and the source of light is established: sunflowers are called the sun, fire, flames, nimbus. The fields of sunflowers in bloom are compared with the objects that may spread in space: ink, sea, burning, fire, light, beam.

The colour of the petals of sunflower in the poetry is yellow. It is most often indicated with the epithets geltonas, $-a$ 'yellow', auksinis, $-\dot{e}$ 'golden', aukso 'gold'. The first one accentuates the saturation of the tone of light, the other one - brightness. Intense yellowness raises the important topic in the poetic space of sunflowers - the poets in this case cannot do without the facts of the biography of Vincent van Gogh who painted the picture "Sunflowers".

Physical peculiarities being raised to the level of ideas and evaluations, a sunflower in bloom becomes the sign of motion, light, prominence, immensity and solitude. In general, it is the visualized metaphor of power. 